9 Beasley RP, Hwang LY. Postnatal infectivity of hepatitis B surface antigencarrier mothers. J Infect Dis 1983;147:185-90.

10 Nair PV, Weissman JY, Tong MJ, Thursby MW, Paul RH, Henneman CE. Efficacy of hepatitis B immune globulin in prevention of perinatal transmission of the hepatitis B virus. Gastroenterology 1984;87:293-8.

11 Dusheiko G. Hepatitis B. In: Bircher J, Benhamou JP, McIntyre N, Rizzetto M, Rodés J, eds. Oxford textbook of clinical hepatology. Oxford: Oxford Medical Publications, 1998:876-96.

12 Higgins JP, Thompson SG. Quantifying heterogeneity in a meta-analysis. Stat Med 2002;21:1539-58.

13 Alderson P, Green S, Higgins J. Cochrane reviewers' handbook 4.2.2 [updated March 2004]. In: Cochrane Library. Chichester, UK: Wiley, 2004.

14 Altman DG, Bland JM. Interaction revisited: the difference between two estimates. BMJ 2003:326:219.

15 Centers for Disease Control and Prevention. Recommendations to prevent hepatitis B virus transmission-United States, updated. Morb Mortal Wkly Rep 1999;48:33-4.

16 David MS, Norman TB. Immunisation against infectious disease. London: HMSO, 1996

17 Yang Y, Liu C, Chen T, Lee M, Chen S, Shi H, et al. Role of hepatitis B immunoglobulin in infants born to hepatitis B e antigen-negative carrier mothers in Taiwan. Pediatr Infect Dis J 2003;22:584-8.
18 Chen W, Gluud C. Vaccines for preventing hepatitis B in health-care workers. Cochrane Database Syst Rev 2005, Issue 4. Art. No. CD000100. DOI: $10.1002 / 14651858 . C D 000100$ pubs.

19 Schroth RJ, Hitchon CA, Uhanova J, Noreddin A, Taback SP, Moffatt MEK, et al. Hepatitis B vaccination for patients with chronic renal failure. Cochrane Database Syst Rev 2004;(3):CD003775

20 Hayashi K, Walker AM. Japanese and American reports of randomized trials: differences in the reporting of adverse effects. Control Clin Trials 1996; 17:99-110.

21 Ioannidis JP, Lau J. Completeness of safety reporting in randomized trials: an evaluation of 7 medical areas. JAMA 2001;285:437-43.

22 Etminan M, Carleton B, Rochon PA. Quantifying adverse drug events: are systematic reviews the answer? Drug Saf 2004:27:757-61.

23 Lee C, Gong Y, Brok J, Boxall EH, Gluud C. Hepatitis B prophylaxis for newborns of hepatitis B surface antigen-positive mothers [protocol for a Cochrane review]. Cochrane Database Syst Rev 2004;(2):CD004790.

24 Zhu Q, Lu Q, Gu X, Xu H, Duan S. A preliminary study on interruption of HBV transmission in uterus. Chin Med J (Engl) 1997;110:145-7.

25 Li XM, Yang YB, Hou HY, Shi ZJ, Shen HM, Teng BQ, et al. Interruption of HBV intrauterine transmission: a clinical study. World J Gastroenterol 2003;9:1501-3.

(Accepted 14 November 2005)

doi 10.1136/bmj.38719.435833.7C

\title{
Trends in sexually transmitted infections in general practice 1990-2000: population based study using data from the UK general practice research database
}

Jackie A Cassell, Catherine H Mercer, Lorna Sutcliffe, Irene Petersen, Amir Islam, M Gary Brook, Jonathan D Ross, George R Kinghorn, Ian Simms, Gwenda Hughes, Azeem Majeed, Judith M Stephenson, Anne M Johnson, Andrew C Hayward

Department of

Primary Care and Population

Sciences, Royal Free and University College Medical School, London NW3 3PF

Jackie A Cassell senior clinical research fellow

Lorna Sutcliffe research coordinator

Irene Petersen research fellow

Amir Islam

research fellow

Andrew C Hayward

senior lecturer in

infectious disease

epidemiology

Azeem Majeed

professor of primary

care and social

medicine

Anne M Johnson

professor of

epidemiology

Centre for Sexual

Health and HIV

Research, Royal

Free and University

College Medical

School, London

WC1E 6 AU

Catherine H Mercer

research fellow

Judith M

Stephenson

reader in

epidemiology

continued over

BMJ 2006;332:332-4

\section{Abstract}

Objective To describe the contribution of primary care to the diagnosis and management of sexually transmitted infections in the United Kingdom, 1990-2000, in the context of increasing incidence of infections in genitourinary medicine clinics.

Design Population based study.

Setting UK primary care.

Participants Patients registered in the UK general practice research database.

Main outcome measures Incidence of diagnosed sexually transmitted infections in primary care and estimation of the proportion of major such infections diagnosed in primary care.

Results An estimated 23.0\% of chlamydia cases in women but only $5.3 \%$ in men were diagnosed and treated in primary care during 1998-2000, along with $49.2 \%$ cases of non-specific urethritis and urethral discharge in men and $5.7 \%$ cases of gonorrhoea in women and $2.9 \%$ in men. Rates of diagnosis in primary care rose substantially in the late 1990s. Conclusions A substantial and increasing number of sexually transmitted infections are diagnosed and treated in primary care in the United Kingdom, with sex ratios differing from those in genitourinary medicine clinics. Large numbers of men are treated in primary care for presumptive sexually transmitted infections.

\section{Introduction}

Diagnoses of sexually transmitted infections from UK genitourinary medicine clinics have increased considerably since the mid-1990s. ${ }^{1}$ The national strategy for sexual health proposed a shift of services for sexually transmitted infections to primary care in England. ${ }^{2}$ Yet little is known about the contribution of general practice to the diagnosis and management of sexually transmitted infections. It has been reported that $16 \%$ of men and 36\% of women diagnosed as having chlamydia in the five years to 2000 were last treated in general practice. ${ }^{3}$ We analysed an anonymised primary care database to explore the contribution of general practice to the diagnosis and management of sexually transmitted infections in the United Kingdom.

\section{Methods}

We estimated the incidence of diagnosed sexually transmitted infections between 1990 and 2000 using a retrospective cohort of patients registered in the UK general practice research database, and surveillance data from genitourinary medicine clinics. ${ }^{4}$ The general practice research database contains the records of about 8 million patients, contributing 36 million patient years of observation. Diagnoses in general practice were based on READ or Oxmis codes and in the genitourinary medicine clinics on published KC60 diagnoses. We estimated the incidence of diagnosed sexually transmitted infections in general practice and calculated the proportion of major sexually transmitted infections that were diagnosed in this setting.

To minimise double counting of patients diagnosed in primary care but treated elsewhere, we distinguished patients who were diagnosed and treated in general practice from those who were not treated and

This article was posted on bmj.com on 26 January 2006: http://bmj.com/ cgi/doi/10.1136/bmj.38726.404120.7C 
Incidence of selected sexually transmitted infections diagnosed and treated in general practice and in genitourinary medicine clinics, 1998-2000, by sex

\begin{tabular}{|c|c|c|c|c|c|}
\hline $\begin{array}{l}\text { Sexually transmitted } \\
\text { infections, by sex }\end{array}$ & $\begin{array}{l}\text { Estimated incidence }(95 \% \\
\text { CI) per } 100000 \text { in general } \\
\text { practice, } 1998-2000\end{array}$ & $\begin{array}{l}\text { Incidence per } \\
100000 \text { in } \\
\text { genitourinary } \\
\text { medicine clinics, } \\
1998-2000\end{array}$ & $\begin{array}{c}\text { Estimated incidence }(95 \% \\
\text { CI) per } 100000 \text { in general } \\
\text { practice and genitourinary } \\
\text { medicine clinics } \\
\text { combined, 1998-2000 }\end{array}$ & $\begin{array}{c}\text { Estimated \% of total } \\
\text { incidence diagnosed } \\
\text { in general practice, } \\
1998-2000\end{array}$ & $\begin{array}{c}\% \text { increase in } \\
\text { estimated incidence } \\
\text { in general practice } \\
1990-2000\end{array}$ \\
\hline \multicolumn{6}{|l|}{ Men: } \\
\hline Gonorrhoea & 1.3 (1.0 to 1.6$)$ & 42.0 & 43.2 (42.9 to 43.6$)$ & 2.9 & 129.7 \\
\hline Genital chlamydia & 5.0 (4.4 to 5.8$)$ & 90.2 & 95.3 (94.6 to 96.0$)$ & 5.3 & 1253.2 \\
\hline Non-specific urethritis & 19.7 (18.4 to 21.1) & 205.8 & 225.4 (224.1 to 226.8) & 8.7 & 65.6 \\
\hline Urethral discharge & 190.6 (186.4 to 194.8$)$ & 11.8 & 202.4 (198.2 to 206.6) & 94.2 & 197.3 \\
\hline $\begin{array}{l}\text { Non-specific urethritis or } \\
\text { urethral discharge }\end{array}$ & 210.3 (204.8 to 215.9) & 217.5 & 427.8 (422.3 to 433.4) & 49.2 & 150.6 \\
\hline Genital warts & 50.9 (48.8 to 53.1) & 256.7 & 307.6 (305.5 to 309.8) & 16.5 & 121.3 \\
\hline Genital herpes & 10.7 (9.7 to 11.7$)$ & 46.0 & 56.7 (55.7 to 57.7) & 18.8 & 46.9 \\
\hline Trichomonas & 1.2 (0.9 to 1.6$)$ & 2.0 & 3.2 (2.9 to 3.6) & 36.5 & -31.4 \\
\hline \multicolumn{6}{|l|}{ Women: } \\
\hline Gonorrhoea & 1.1 (0.8 to 1.5$)$ & 18.5 & 19.6 (19.4 to 20.0 ) & 5.7 & 175.4 \\
\hline Genital chlamydia & 34.7 (33.0 to 36.5$)$ & 116.4 & 151.2 (149.4 to 153.0$)$ & 23.0 & 2494.8 \\
\hline Genital warts & 49.3 (47.2 to 51.4$)$ & 187.0 & 236.2 (234.2 to 238.4) & 20.9 & 19.2 \\
\hline Genital herpes & 31.0 (29.1 to 32.7$)$ & 61.3 & 92.3 (90.7 to 94.0$)$ & 33.6 & 303.9 \\
\hline Trichomonas & 14.7 (13.4 to 15.9 ) & 19.9 & 34.6 (33.3 to 35.8 ) & 42.5 & -28.3 \\
\hline
\end{tabular}

therefore may have been referred elsewhere. We reviewed individual patient records when a diagnosis of chlamydia, gonorrhoea, trichomonas, or nonspecific urethritis or urethral discharge was recorded during 1998-2000. We estimated sexually transmitted infections diagnosed in general practice separately from those diagnosed and treated in general practice. It was assumed that all patients diagnosed in a genitourinary medicine clinic were treated there. We then compared the incidence of sexually transmitted infections diagnosed and treated in general practice with the incidence of selected sexually transmitted infections diagnosed in genitourinary medicine clinics in the United Kingdom during 1998-2000.

\section{Results}

The percentage increase in sexually transmitted infections diagnosed in primary care during 1990-2000 was greatest for genital chlamydia (1253\% in men, 2495\% in women) and consistent with the increases found in genitourinary medicine clinics (table). ${ }^{5}$

Among incident cases recorded in general practice, evidence existed of treatment for $58.4 \%$ cases of chlamydia, $97.4 \%$ cases of non-specific urethritis or urethral discharge, and $46.2 \%$ cases of gonorrhoea. A large number of men with urethral discharge seem to be treated syndromically (without a microbiological diagnosis) in general practice, using antibiotics appropriate for non-specific urethritis. The age distribution of urethral discharge was similar to that of non-specific urethritis and chlamydia in men, with a peak in the 20-24 year old age group typical of the epidemiology of sexually transmitted infections in men. ${ }^{1}$ The incidence of chlamydia and gonorrhoea in women in general practice peaked in the 16-19 year old age group, as in genitourinary medicine clinics.

The sex ratio of most diagnoses of sexually transmitted infections differed between general practice and genitourinary medicine clinics. The men:women ratio for treated chlamydia was $0.77: 1$ in genitourinary medicine clinics compared with $0.14: 1$ in general practice, whereas the respective ratios for treated gonorrhoea were 2.27:1 and 1.12:1 and for genital herpes were $0.75: 1$ and $0.34: 1$

\section{Discussion}

A substantial and increasing number of sexually transmitted infections are diagnosed and treated in general practice and may reflect increasing engagement of general practitioners with sexual health. Rates of diagnosed sexually transmitted infections in the United Kingdom are higher than those captured by current surveillance based only on genitourinary medicine clinics. ${ }^{5}$ Significant numbers of men are treated in general practice for symptoms suggestive of sexually transmitted infections.

Contributors: JAC had the original idea for the study and obtained funding. JAC, CHM, LS, AMJ, IP, AI, AM, MGB, JDR, JS, GRK, IS, and GH planned the strategy for analysis of the data. All authors reviewed the codes, further developed the analytic strategy, and drafted and revised the paper. IP and AI led the data extraction. The work was discussed and developed through departmental research seminars, to which all authors and numerous unnamed others contributed. JAC and CHM are guarantors. The views expressed are those of the authors and not necessarily those of the Medical Research Council or the

\section{What is already known on this topic}

Current surveillance of sexually transmitted infections based on genitourinary medicine clinics underestimates the burden of disease

\section{What this study adds}

The diagnosed incidence of sexually transmitted infections in the United Kingdom is higher than previously thought, with an increasing contribution from general practice

Men are commonly treated syndromically, and the sex ratios of diagnoses in general practice differ substantially from those in genitourinary medicine clinics health departments.
Patrick Clements

Clinic, Central

Middlesex Hospital,

London NW10 7NS

M Gary Brook

consultant

genitourinary

physician

Whittall Street

Clinic, Birmingham B4 $6 \mathrm{DH}$

Jonathan D Ross

consultant

genitourinary

physician

Royal Hallamshire Hospital, Sheffield S10 2JF

George R Kinghorn consultant genitourinary physician

Centre for Infections (Communicable Disease

Centre), Health

Protection Agency,

London NW9 5EQ

Ian Simms

senior epidemiological scientist

General Practice

Research Database

Division, Medicines

and Healthcare

Regulatory Agency,

London SW8 5NQ

Gwenda Hughes

head of research

services

Correspondence to:

$\mathrm{J}$ A Cassell

j.cassell@

pcps.ucl.ac.uk 
Funding: This study was funded by the Medical Research Council, with funding allocated from the health departments under the aegis of the Medical Research Council and UK health departments Sexual Health and HIV Research Strategy Committee.

Competing interests: None declared.

Ethical approval: Scientific and Ethical Advisory Group of the general practice research database.

1 Health Protection Agency. Focus on prevention. HIV and other sexually transmitted infections in the United Kingdom in 2003. Annual report. London: HPA, Nov 2004
2 Department of Health. The national strategy for sexual health and HIV. London: DoH, 2001.

3 Fenton KA, Korovessis C, Johnson AM, McCadden A, McManus S, Wellings K, et al. Sexual behaviour in Britain: reported sexually transmitted infections and prevalent genital Chlamydia trachomatis infection. Lance 2001;358:1851-4.

4 Majeed A. Sources, uses, strengths and limitations of data collected in primary care in England. Health Stat Q 2004;(21):5-14.

PHLS, DHSS\&PS, and Scottish ISD(D)5 Collaborative Group. Trends in sexually transmitted infections in the United Kingdom 1990-1999. London: Public Health Laboratory Service, 2000.

(Accepted 17 November 2005)

doi $10.1136 /$ bmj.38726.404120.7C

\section{Timing of mortality among internally displaced persons due to the tsunami in Sri Lanka: cross sectional household survey}

Nobuyuki Nishikiori, Tomoko Abe, Dehiwala G M Costa, Samath D Dharmaratne, Osamu Kunii, Kazuhiko Moji

Research Center for Tropical Infectious Diseases, Institute of Tropical Medicine, Nagasaki University 1-12-4 Sakamoto,

Nagasaki 852-8523, Japan

Nobuyuki Nishikiori assistant professor

Tomoko Abe PhD student

Osamu Kunii professor

Kazuhiko Moji professor

Department of Community

Medicine, Faculty of

Medicine,

University of

Peradeniya, Kandy,

Sri Lanka

Dehiwala G M

Costa

Postgraduate Institute

of Medicine trainee

Samath D

Dharmaratne

senior lecturer

Correspondence to:

N Nishikiori

nobu@net.nagasaki-u.

ac.jp

BMJ 2006;332:334-5

\section{Abstract}

Objective To describe the distribution of mortality among internally displaced persons during two and a half months after the Indian Ocean tsunami, 2004. Design Cross sectional household survey with retrospective cohort analysis of mortality.

Setting Camps for internally displaced persons due to the tsunami in an eastern coastal district of Sri Lanka. Participants 3533 people from 859 households accommodated in 13 camps.

Main outcome measures All cause death and number of missing people.

Results 446 deaths and 11 missing people were reported after the 2004 tsunami, of which most (99\%) occurred on the day of the tsunami or within three days thereafter. No deaths were reported for the two and a half month period starting one week after the tsunami.

Conclusions Most mortality after the 2004 tsunami occurred within the first few days of the disaster and was low in the study area.

\section{Introduction}

On 26 December 2004, the most devastating tsunami in recorded history hit the countries around the Indian Ocean. Sri Lanka was the second most affected country, with more than 30000 deaths and half a million people displaced. We carried out a cross sectional household survey in an eastern coastal district of Sri Lanka to describe the distribution of mortality during and after the disaster among internally displaced persons.

\section{Methods}

We carried out our survey from 13 to 18 March 2005. Internally displaced persons were highly mobile, making it difficult to define the sampling framework, thus we included all households in 13 camps in three administrative divisions of Ampara district. After

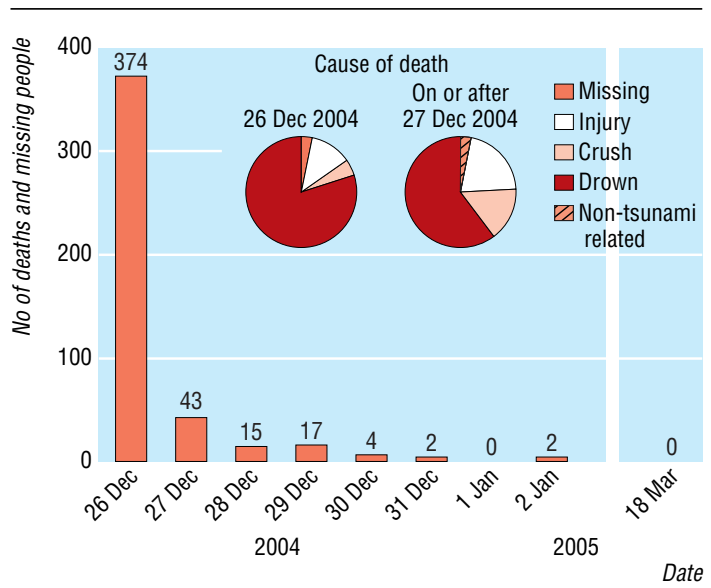

Distribution of 446 deaths and 11 missing people by date among 3533 displaced persons in Ampara district, Sri Lanka on 26 December 2004, day of the tsunami, and subsequent days

written informed consent was obtained, a householder was asked to provide information on all family members as of 25 December 2004 (the day before the tsunami) and any subsequent deaths and missing events. Information on the family was verified by referring to the household registration card, issued by the local government for food rations.

\section{Results}

The study sample consisted of 3533 people from 859 households that gave consent to be surveyed. Of a total of 446 deaths and 11 missing people, most (99\%) occurred on the day of the tsunami or within three days thereafter (figure). No death was observed after 2 January 2005 , the seventh day after the tsunami, indicating low mortality for a displaced population after

This article was posted on bmj.com on 6 January 2006: http://bmj.com/ cgi/doi/10.1136/bmj.38693.465023.7C 